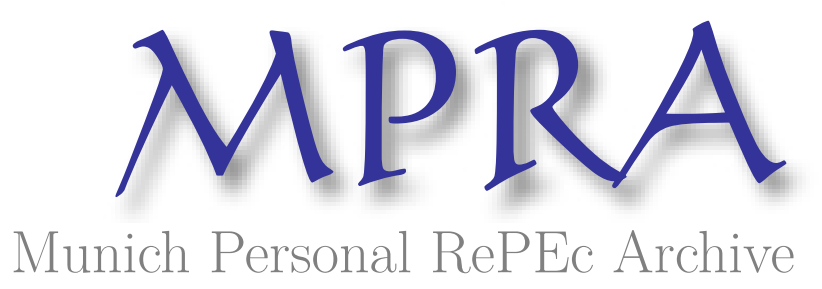

\title{
A Commodity Curse? The Dynamic Effects of Commodity Prices on Fiscal Performance in Latin America
}

Medina, Leandro

CAF

January 2010

Online at https://mpra.ub.uni-muenchen.de/21690/

MPRA Paper No. 21690, posted 29 Mar 2010 06:34 UTC 


\title{
A Commodity Curse? \\ The Dynamic Effects of Commodity Prices on Fiscal Performance in Latin America
}

\author{
Leandro Medina $^{1}$
}

Version: January 2010

\begin{abstract}
The recent boom and bust in commodity prices has raised concerns about the impact of volatile commodity prices on Latin American countries' fiscal positions. Using a novel quarterly datasetwhich includes unique country specific commodity price indices and a comprehensive measure of public expenditures- this paper analyzes the dynamic effects of commodity price fluctuations on fiscal revenues and expenditures for 8 commodity exporting Latin American countries. The results indicate that Latin American countries' fiscal positions generally react strongly to shocks to commodity prices, yet there are marked differences across countries in observed reactions. Fiscal variables in Venezuela display the highest sensitivity to commodity price shocks, with expenditures reacting significantly more than revenues. On the other side of the spectrum, Chile's fiscal indicators react very little to commodity price fluctuations, and their dynamic responses are very similar to those seen in high-income commodity exporting countries. A plausible explanation to this distinct behavior across countries could be related to the efficient application of fiscal rules, accompanied by strong institutions, political commitment and high standards of transparency.
\end{abstract}

JEL Classification Numbers: E62, H50, O13.

\footnotetext{
${ }^{1} \mathrm{Ph}$. D. Candidate, The George Washington University, Department of Economics.

Email: leandrom@gwmail.gwu.edu.

Financial support from the CAF is gratefully acknowledged. The author wishes to thank the helpful comments of Adriana Arreaza, Ana Corbacho, Gabriel Di Bella, Fred Joutz, Herman Kamil, Graciela Kaminsky, Tara Sinclair, Antonio Spilimbergo and participants at LACEA 2009 Conference held in Buenos Aires, Argentina. Special thanks to Carlos Prada for his help with commodity price data. The views expressed herein are those of the author and not necessarily represent those of the IMF or IMF policy.
} 


\section{INTRODUCTION}

The recent boom and bust in commodity prices has raised concerns about the impact of commodity prices on Latin American countries' fiscal positions. From 2004 to almost the end of 2008, rising commodity prices boosted tax revenues, foreign direct investment, and overall economic activity in many countries in Latin America (LA). While some governments in the region saved a large proportion of buoyant revenues and accumulated financial assets, others used revenue windfalls to fuel growing government spending. However, the recent plunge in commodity prices and global trade since late 2008 has affected net commodity-producing countries (Figure 1). As a result, government finances have come under pressure in many countries in the region.

Episodes of booms and busts in commodity prices generate volatility in the fiscal revenues of emerging commodity-exporting countries (Figure 2). Some governments, assuming that a boom in prices may be permanent, increase expenditures more than proportionally. Once the government expenditures rise (and when the effects of the boom have faded out) it is very difficult to lower them, such as described in Boccara (1994). Since this kind of behavior seems to be quite pervasive in the region, it is important to explore its causes and consequences.

Recent literature has typically focused on documenting the reaction of fiscal positions to the output cycle and only indirectly linking commodity price fluctuations with fiscal outcomes, looking at the impact of commodity prices only through their effect on GDP. 
For instance, Gavin and Perotti (1997) identify the procyclicality of fiscal policy in LA particularly in periods of low growth. Talvi and Végh (2005) generalized this claim to all developing countries. Kaminsky, Reinhart and Végh (2004) not only find evidence of procyclicality of fiscal policy, capital flows and monetary policy in developing countries, particularly in middle-high income countries, but also analyze which indicators are appropriate to measure the procyclical behavior. Ilzetzki and Végh (2008) discover evidence of the procyclicality of fiscal policy in developing countries and that it is expansionary. The explanation for this procyclical behavior has been attributed to international credit constraints and political distortions in the literature, ${ }^{2}$ but the literature has not focused on the direct impact of external shocks on fiscal positions.

To account for the cyclicality of fiscal policy, several measures have been used. Ilzetzki and Végh (2008) use government consumption (from the national accounts); Kaminsky et. al. (2004) utilize government spending, while Gavin and Perotti (1997) and Alesina and Tabellini (2005) exploit the fiscal deficit. The use of government consumption is not very convenient from a comprehensive discretionary perspective, because it does not take into consideration government investment (capital expenditures), key in emerging exporting economies especially during commodity price booms. With respect to the use of fiscal balance, the problem is that it is difficult to extract the effect of an external shock, because when a positive shock hits, government revenues increase right away due to the increase in export taxes, particularly in commodity exporting countries. Therefore, using fiscal deficit as the variable of interest, one could erroneously say that there is no

\footnotetext{
${ }^{2}$ On the international credit constraint literature see Gavin and Perotti (1997), Riascos and Végh (2003), and Caballero and Krishnamurthy (2004). With respect to the literature on political distortions, see Tornell and Lane (1999), Talvi and Végh (2005), Alesina and Tabellini (2005) and Ilzetzki (2008).
} 
impact of external shocks on fiscal positions, while what is really happening is that there is an impact in both revenues (automatically through export taxes) and expenditures (discretionary).

Research has also referred to the impact of commodity price shocks on economic aggregates. Hirschman (1977) cites the mid-nineteenth-century Peruvian guano boom, the benefits of which were misspent in railway investments; Collier and Gunning (1994) attribute the Egyptian loss of the Suez Canal to the unsustainable Egyptian publicexpenditure programs following the cotton-price boom during the U.S. Civil War. Deaton and Miller (1995) assess the impact of commodity price shocks on Sub-Saharan Africa and discuss whether poor macroeconomic results should be attributed to the inherent difficulty of predicting commodity-price fluctuations or, rather, to flawed internal political and fiscal arrangements. Raddatz (2007) finds that, among external shocks, commodity prices are the most important source of fluctuation on low income countries' per-capita GDP and that, in response to shocks, the government expenditure and the current account tend to move in tandem with total GDP. However, this literature has not analyzed the dynamic responses of fiscal positions to the commodity price shocks.

To look at the impact of commodity prices on economic aggregates, some studies have constructed country specific commodity price indices. For example, Deaton and Miller (1995) assembled a measure of export prices for 32 countries. For each one of the countries, they calculated the total value of exports of 21 commodities in 1975 and weight them by dividing the value of each commodity's exports in 1975 by this total. The weights are then held constant for the rest of the exercise and are applied to the world 
prices of the same commodities. Collier and Goderis (2007) constructed a commodity export price index composed by agricultural and non-agricultural commodities at a yearly frequency with fixed commodity export weights; to allow the effect of commodity export price to be larger for countries with larger exports, they weight the index by the share of commodity exports in GDP. The use of fixed weights in these indices does not allow accounting for the impact of changes in the trade shares.

Taking into account the literature above, as well as the unprecedented magnitude of the last boom and bust behavior of commodity prices, an analysis that focuses on understanding the direct impact of commodity prices on fiscal positions is needed. This paper makes three contributions to the existing literature: (i) it uses a novel quarterly dataset that includes a unique country specific commodity price index, that allows to look at changes in commodity prices and changes in the commodity export shares (ii) it exploits a comprehensive measure of public expenditure and (iii) it analyses the dynamic effects of commodity prices on revenues, expenditures and GDP using VAR methodology that relies on Cholesky decomposition of matrices for the identification strategy. The novelty of this approach is that I will estimate the impact of commodity price shocks on fiscal variables using a unique dataset, while the existing empirical studies focus typically on the procyclicality of fiscal variables (government expenditure, primary surplus) with respect to GDP and on the impact of fiscal variables on GDP (fiscal multiplier). 
The results of the estimations indicate that LA countries fiscal positions generally react strongly to positive shocks to commodity prices, however, they highlight that there exists a spectrum of responses. Within this spectrum Chile behaves like an outlier in the LA region with dynamic fiscal responses to commodity prices fluctuations very similar to the high-income commodity exporting countries, such as Australia, Canada, New Zealand and Norway. At the other end of the spectrum is Venezuela where expenditures rise even more than proportionally than revenues when faced with a commodity price shock.

The remainder of this paper is organized as follows: The next section includes the description of a suggested methodology to study the impact of commodity prices on fiscal positions and describes the data used. The third section describes and analyses the main results. The last section concludes and suggests possible avenues for future research.

\section{COMMODITY PRICES AND THEIR DYNAMIC IMPACT ON FISCAL POSITIONS: A SUGGESTED METHODOLOGY}

\section{Vector Autoregression (VAR) approach}

To estimate the effects of commodity price shocks on fiscal positions, I will estimate a VAR model using as identification strategy the Cholesky decomposition of matrices. A desirable property of VARs (given the purpose of this exercise) is that they focus on the impact of shocks. First the relevant shocks are identified, and the response of the system 
to shocks is described by analyzing impulse responses (the propagation mechanism). Furthermore, the use of variance decomposition analysis will allow me to quantify the relative importance of commodity price shocks as sources of expenditures, revenues and GDP fluctuations. Another advantage of using VARs over cross-sectional regressions is the ability to look at the dynamic effects of commodity price shocks on fiscal revenues and expenditures. The cross-sectional method only estimates a one period effect. Furthermore, this econometric method permits to disentangle commodity price' direct and indirect effect on fiscal positions (through their effect on GDP).

To identify the structural parameters, a set of restrictions must be specified. Following Sims (1980), the reduced form errors are orthogonalized by Cholesky decomposition. The ordering is characterized as follows: the Country Specific Commodity Price Index (CSCPI) will be ordered last assuming that countries are small enough to be price takers. Given that the literature on procyclicality has emphasized the effects of GDP on fiscal policy, after the CSCPI will be the GDP, and then expenditures and revenues. The ordering is consistent with the literature that highlights the effects of external shocks on economic aggregates, the procyclicality of fiscal policy and the nexus between public revenues and expenditures.

The VAR is estimated using quarterly data. All the variables are expressed in log of the real level and the model is estimated in first differences ${ }^{3}$. The latter, because standard

\footnotetext{
${ }^{3}$ Similar results are obtained by using the cyclical component from linear quadratic detrending and Hodrick-Prescott filter.
} 
unit root tests show that the variables are stationary in first differences. The number of included lags ( 1 to 6 ) was determined based on the Hannan-Quinn information criterion.

\section{Data}

In order to study the effects of commodity price fluctuations on fiscal positions, I will use a novel database for 12 commodity exporting countries, covering a period that spans as early as the first quarter of 1975 to as late as the last quarter of 2008, but differs from country to country. This dataset will use unique Country Specific Commodity Price Indices (CSCPI) that combine international prices of 55 commodities (IMF, monthly commodity price indices) and commodity export shares by country (from the Standard International Trade Classification, SITC, found in the World Integrated Trade Solutions, WITS). The CSCPI will allow me to look not only at changes of commodity prices, but also at the composition of commodity exports.

For this exercise a sample of 12 countries was selected: the Latin American largest commodity exporting countries and four high income commodity exporting countries. The Latin American sample includes Argentina, Brazil, Chile, Colombia, Ecuador, Mexico, Peru and Venezuela. These countries account for more than 92 percent of LA's GDP. Furthermore, their commodity exports represent, on average, more than 55 percent of total exports of goods, which also represent a large share of GDP (Table 1). In order to compare the performance of LA with other economies with similar features, four high 
income commodity exporting countries were added to the sample: Australia, Canada, New Zealand and Norway.

The variables of interest are government primary expenditures, revenues, real GDP and the Country Specific Commodity Price Indices (CSCPI). Government revenues and primary expenditure for the Non Financial Public Sector (NFPS) were used because they give a broader aggregation level. When these series were not available at this level, Central Government variables were utilized. See the Appendix for a more detailed description of the data used and its sources.

The CSCPI is based on both the IMF monthly commodity price indices and the trade information from the Standard International Trade Classification (SITC) found in the World Integrated Trade Solution (WITS) ${ }^{4}$.

The procedure to create the CSCPI requires linking commodity prices from the IMF with the commodity's trade value from the WITS. When the commodity is found in both datasets, this relationship is direct. Nonetheless, the link could be indirect since the information from the IMF has only 55 commodities while the WITS has 196. Linking these data requires some assumptions: either more than one commodity from the WITS could be classified in the same commodity group of the IMF or some of the commodities in the WITS could not be linked to a commodity price in the IMF dataset. It is important to note that the frequency of the information is also different. The IMF database is monthly while the WITS is annual. In order to take advantage of the high frequency for

\footnotetext{
${ }^{4}$ It is important to clarify that the SITC has 3 revisions. In this case, I use the third one because it includes more commodities than the previous data. Data could be disaggregated into 3 or 4 digits.
} 
the prices database, I assume the weights for each commodity are the same for each year throughout the sample period. The weights reflect, on average, 80 to 90 percent of the total commodity exports.

All variables are expressed in real terms. Whenever the original series were not in real terms, the nominal variables were deflated by the Consumer Price Index. All series are in logs and, when not reported in seasonally-adjusted terms (except for the CSCPI), they are adjusted using the X-12 quarterly seasonal adjustment method ${ }^{5}$.

As the presented data follows a nonstationary process, tests for unit roots were performed and the unit roots hypothesis was not rejected. Furthermore, Johansen cointegration procedure was performed for all the variables in the system and the results shows that there is no cointegration vector under the model considered. In consequence, these series were adjusted to be stationary in order to be included in the VAR estimation. The results are robust to other specifications, such as the cyclical component of the series obtained by using the Hodrick-Prescott filter.

\section{RESULTS}

\section{The dynamic responses of fiscal variables to commodity price shocks}

\subsection{The size of the shock}

\footnotetext{
${ }^{5}$ This method ( published by the U. S. Department of Commerce, U. S. Census Bureau) modifies the X-11 variant of Census Method II by J. Shiskin A.H. Young and J.C. Musgrave of February, 1967.
} 
When looking at the country specific commodity prices, one can observe a significant acceleration in commodity prices starting at the end of 2003, tendency that lasted till september of 2008 where there was a bust. Nevertheless prices never returned to their pre-2003 levels.

When computing the price shocks in the VARs, on average, the size of the one standard deviation shock in LAC countries is of around 13 percent, being Venezuela the largest with 16.4 percent and Brazil the smallest with 7.8 percent (Figure 4). With respect to high-income commodity exporters, the largest on impact response is that of Norway, that reaches almost 10 percent.

Another interesting feature of these indices -that affect the size of the shocks- is their composition. While Argentina mainly focus on soy and beef, other LA countries and high-income commodity exporters heavily rely on metals, minerals and oil. The exception to the high-income group is New Zealand (Table 2).

\subsection{Impulse response function analysis}

The estimated accumulated impulse response functions are shown in Figures 5, 6, 7 and 8. Dotted lines reflect one-standard deviation bands. The solid line represents the respective accumulated response to Cholesky one standard deviation commodity price shocks. 
For both LA and high-income countries, positive commodity price shocks have the expected positive impact on real revenues and GDP. A one-standard deviation shock to commodity prices in a quarter leads to a rise in government real revenues that range from around 2 percent in Brazil and Canada, to 10 percent in Venezuela and around 14 percent in Ecuador. With respect to GDP, the same shock generates a response that varies from around 1 percent in Australia, to 2.5 percent and 3 percent in Argentina and Norway respectively. In most cases, the peak response of revenues and GDP occur two quarters after the shock (Table 5).

Compared with the behavior of revenues and GDP, however, the response primary expenditures to commodity prices is substantially more heterogeneous across Latin American countries. A positive innovation to the commodity price leads to responses that range from 0 percent in the case of Chile, to an increase of almost 12 percent in Venezuela. ${ }^{6}$ The median response is around 4 percent, and the second largest response (from Colombia) is less than 8 percent, indicating that Venezuela behaves like an outlier in the regional context (Figure 6).

In the case of high-income commodity exporters, a standard deviation in the commodity price shock in a quarter, leads to no reaction of primary expenditures in Australia and New Zealand. In Canada and Norway, primary expenditures actually decrease on impact

\footnotetext{
${ }^{6}$ The results for Chile are consistent with findings by other authors, like Kaminsky et. al. (2004) and Calderon and Schmidt-Hebbel (2003).
} 
(with reactions of -0.2 percent and -1.5 percent, respectively), suggesting a countercyclical fiscal policy.

Taken together, the results show that while both LA and high-income countries revenues and GDP react positively to commodity price shocks, a completely different set of results is found when looking at the impact in primary expenditures. Within LA there is a wide dispersion in country's responses, with Venezuela and Chile at opposing ends of the spectrum of responses. The response of fiscal indicators in Chile, in particular, resemble those seen in high-income commodity exporting countries.

\subsection{Variance decomposition analysis}

To quantify the contribution of commodity price shocks to fluctuations in government expenditures, I estimate variance decomposition of forecast errors. Interestingly, the results from this analysis (Table 3 and Figure 3 ) show that commodity price fluctuations play a dominant role in Venezuela (the highest), accounting for almost 17 percent of government spending fluctuations at a 10 quarters horizon. In Chile, on the hand, commodity price fluctuations hardly explain expenditure fluctuations at all, accounting for less than 4 percent in the same time horizon, almost four times less than in Venezuela. All other LA countries lie in between Chile and Venezuela, with an average contribution (excluding Venezuela and Chile) of 9.5 percent at a 10 quarters horizon. 
Results for high-income commodity exporting countries indicate that, on average, commodity price fluctuations explain a smaller fraction of government expenditures fluctuations than in LA countries, averaging 3.8 percent at a 10 quarters horizon.

\section{Looking at fiscal rules}

A possible explanation to the different behavior in expenditures is likely related to the heterogeneous institutional frameworks that govern fiscal policy decisions. For instance, Corbacho and Schwartz (2007) suggest that for Argentina, Colombia and Peru fiscal performance continued to worsen after the fiscal responsibility laws were implemented (Argentina in 1999, Colombia in 2003 and Peru in 1999). These laws “...fail to substitute for political commitment and society's support for needed fiscal consolidation. Numerical targets where successively breached, undermining credibility in the fiscal framework established in the law". With respect to Chile, Kaminsky et. al. (2004) and Calderon and Schmidt-Hebbel (2003) find evidence that supports the hypothesis that a country with better fundamentals, stronger institutions and more stable policy rules, would be able to pursue counter-cyclical policies. The adoption of fiscal rules specifically designed to encourage public saving in good times may have helped in this effort in the case of Chile.

When looking at high-income commodity exporting countries, either formal or informal fiscal rules seem to be accompanied by strong institutions, political commitment and high standards of transparency, which allow fiscal rules to work. According to Bhattacharyya 
and Williamson (2009) commodity price shocks that matched most of the primaryproduct exporting countries, never caused the same volatility in Australia (either in aggregates, or in sectoral and regional performance). The explanation is that (i) revenues come from fairly diverse sources so that commodity price volatility do not produce as great revenue volatility; (ii) diversification offsets the impact of commodity price shocks; a big and growing industrial sector before the seventies and a big and growing service sector after that period seems to make the difference.

In the case of Canada, its strong fiscal record in recent years rests on a proven budgetary framework, including a well-establish forecasting process. Canadian public finances are highly transparent, and the prudent fiscal policies of recent governments have had public support. Unlike in many other countries, fiscal policy is not constrained by budget rules imposed under the constitution or the law. Between 1998 and 2006, Canada followed a de facto fiscal rule of "budget balance". The conservative government that took power in 2006 abandoned this rule in favor of targeting a moderate surplus of 0.25 percent of GDP.

For New Zealand, by early 1990's, policy advice was oriented toward fiscal consolidation and a medium-term focus. Changes to the institutional framework were made, following the introduction of the Fiscal Responsibility Act (1994). The Act is based on "principles" of responsible fiscal management, including strong disclosure and reporting requirements, but does not set fixed numerical targets. 
In order to manage Norway's oil wealth a Government Petroleum Fund was establish in 1990. It receives most of the petroleum revenue and invests it in financial assets abroad. The key fiscal rule sets non-oil structural budget deficit of the central government to be 4 percent (allowing for temporary deviations over the business cycle). The fund was created to preserve assets for future generations and avoid potential crowding out effects (Dutch disease) that the rapid spending of oil wealth might carry.

\section{CONCLUSION}

In light of the recent boom and bust in commodity prices, concerns have been raised about the impact of commodity prices on Latin American countries' fiscal positions. Given that the size of the last shock has been unprecedentedly large it is important to study its effect on commodity exporting countries' fiscal positions.

This paper estimates the dynamic effects of commodity price shocks in a group of LA commodity exporting countries and compares VAR impulse responses functions with those of high-income commodity exporting countries. This methodology exploits the use of a unique quarterly dataset that includes a novel country specific commodity price index. The results of the estimations show that the impact in revenues is not that different among the two groups of countries. In contrast, there is a spectrum of primary expenditures responses within LA countries, being Chile and Venezuela the extremes of the distribution. Furthermore, Chile behaves similar to high-income countries. 
A potential explanation to this behavior could be the efficient application of fiscal rules, accompanied by strong institutions, political commitment and high standards of transparency. This hypothesis has been recognized by other literature, where there seems to be agreement about the influence of fiscal institutions on fiscal performance (Corbacho and Schwartz (2007)). A possible next step for this research would be to look for structural breaks in countries that during the last decade adopted fiscal rules, to be able to detect changes in fiscal behavior and establish if there is a clear empirical link with such rules. 


\section{REFERENCES}

Alesina, A. and G. Tabellini; "Why is Fiscal Policy Often Procyclical?” NBER Working Paper No. 11600; 2005.

Bhattacharyya S. and J. Williamson; "Commodity Price Shocks and the Australian Economy Since Federation”; NBER Working Paper No. 14694; 2009.

Blanchard O. and R. Perotti; "An Empirical Characterization of the Dynamics Effects of Changes in Government Spending and Taxes on Output”; NBER, 1999.

Boccara B. ;"Why Fiscal Spending Persists When a Boom in Primary Commodities Ends"; The World Bank; 1994.

Caballero, R. J., and A. Krishnamurthy; "Fiscal policy and financial depth"; NBER Working Paper No. 10532. 2004.

Calderon C. and K. Schmidt-Hebbel; "Macroeconomic Policies and Performance in Latin America"; Journal of International Money and Finance; Vol. 22; pp. 895-923; 2003.

Calderon C. and P. Fajnzylber; "How Much Room Does Latin America And The Caribbean Have For Implementing Counter-Cyclical Fiscal Policies?”; April, 2009. 
Collier P. and B. Goderis; "Commodity Prices, Growth and the Natural Resource Curse:

Reconciling a Conundrum"; University of Oxfords; 2007.

Collier P. and J. Gunning; "Trade Shocks: Consequences and Policy Responses in Developing Countries"; San Francisco; International Center for Economic Growth; 1994.

Corbacho A. and Schwartz G; "Fiscal Responsibility Laws" in Kumar, M. S. and TerMinassian T.(eds);"'Promoting Fiscal Discipline”; International Monetary Fund; 2007.

Deaton A. and R. Miller; "International Commodity Prices, Macroeconomic Performance, and Politics in Sub-Saharan Africa"; Princeton Studies in International Finance 79. 1995.

Gavin M. and R. Perotti; "Fiscal Policy in Latin America": NBER Macroeconomics Annual. 1997.

Hirschman A.; "A Generalized Linkage Approach to Development, with Special Reference to Staples"; Economic Development and Cultural Change; 25; 1977.

Hodrick R. and Prescott E.; "Postwar U.S. Business Cycles: An Empirical Investigation"; Journal of Money, Credit, and Banking; 1997. 
Ilzetzki, E.; "Rent-seeking distortions and fiscal pro-cyclicality." University of Maryland, manuscript, December 2008.

Ilzetzki, E., and C.A. Végh: “ Pro-cyclical fiscal policy in developing countries: Truth or fiction?”; NBER Working Paper 14191, July 2008.

International Monetary Fund; Western Hemisphere: Regional Economic Outlook; "Saving for a Rainy Day? Sensitivity of LAC Fiscal Positions to Commodity Prices"; Di Bella G., H. Kamil and L. Medina; 2009.

International Monetary Fund: "Norway: Selected Issues”; Rossi M., Jafarov E. and Leigh D.; May 2007.

International Monetary Fund: "Western Hemisphere: Regional Economic Outlook"; April 2008.

Kaminsky, G.L., C.M. Reinhart, and C.A. Végh; "When it rains, it pours: Procyclical capital flows and macroeconomic policies." In: Gertler, M., and K. Rogoff, eds., NBER Macroeconomics Annual 2004. Cambridge, MA: The MIT Press 2005.

Perron P.; "The Great Crash, the Oil Price Shock, and the Unit Root Hypothesis"; Econometrica 57 Nov 1989. 
Perotti R.; "Fiscal Policy in Developing Countries: A Framework and Some Questions"; The World Bank: 2007.

Raddatz C.; "Are external shocks responsible for the instability of output in low-income countries?"; Journal of Development Economics; Elsevier, vol. 84(1), pages 155-187; September 2007.

Riascos A. and C. A. Végh; "Procyclical Government Spending in Developing Countries: The Role of Capital Market Imperfections."; mimeo, UCLA and Banco Republica, Colombia; 2003.

Sims, C.; "Macroeconomics and Reality"; Econometrica; 48(1); 1980.

Talvi E. and C. A. Végh ;"Tax Base Variability and Pro-cyclical Fiscal Policy in Developing Countries"; Journal of Development Economics 78 (1): 156-190. 2005.

Tornell A. and P. Lane; "Are windfalls a curse? A nonrepresentative agent model of the current account"; Journal of International Economics 44, pp. 83-112; 1998.

Tornell A. and P. Lane; "The Voracity Effect"; American Economic Review, Vol. 89; 1999, pp. 22-46. 


\section{APPENDIX}

\section{Data}

The Data presented in this paper goes as far as the first quarter of 1975. For more information about the length of the time series for each country please see Table 4. Next is a description of the series and data sources.

\section{Country Specific Commodity Price Indices}

Author's estimations based on the IMF monthly commodity price indices and the trade data from the Standard International Trade Classification (SITC) found in the World Integrated Trade Solution (WITS).

\section{Real GDP}

Data was obtained by Haver Analytics using primary data from each country's authorities. When real data was not available, nominal data was deflated by each country's CPI.

\section{CPI}

The series on CPI were obtained by Haver Analytics using primary data from each country's authorities.

\section{Revenues and Primary Expenditures}


Revenues encompass total revenues and the aggregation level depends on each country's data availability. In the case of primary expenditures, the variable cover total expenditures (i.e. current expenditures plus capital expenditures) minus interest payments; aggregation level depending also on country's definitions and data availability.

For Argentina, author's estimations from the Non-Financial Public Sector data, published by the Finance Ministry. In the case of Australia, Central Government aggregation data from the Reserve Bank of Australia. For Brazil, the series were used at a Central Government level (including Federal Government, Central Bank and Social Security Administration) from the Central Bank database. Data for Canada was obtained by Haver Analytics using primary data from Canada's Department of Finance at a Federal Government aggregation level. The series for Chile were obtain from the Finance Ministry at a Central Government level. For Colombia, data for the Non-Financial Public Sector was gathered from the Finance Ministry's CONFIS. In the case of Ecuador, the data was obtained at a Non-Financial Public Sector level from Ecuador's Central Bank. For Mexico, Central Government data was acquired from the Finance and Public Credit Department. New Zealand data on government revenues and expenditures were not available at a quarterly basis, therefore, data on government consumption were used (from the country's national accounts). The series for Norway were gathered at a Central Government level (including National Insurance Scheme) from Statistics Norway. For Peru, data was obtained at a Central Government level from Peru's Central Bank. In the 
case of Venezuela, data was gathered at a Central Government level from Venezuela's Central Bank. 
Table 1. The Importance of Commodity Exports

(In percentage)

\begin{tabular}{|c|c|c|}
\hline & $\begin{array}{c}\text { As a Share of Total } \\
\text { Merchandise } \\
\text { Exports } 1 /\end{array}$ & $\begin{array}{c}\text { As a Share of GDP } \\
1 /\end{array}$ \\
\hline \multicolumn{3}{|c|}{ Latin American Countries } \\
\hline Argentina (ARG) & 55.6 & 11.2 \\
\hline Brazil (BRA) & 41.0 & 5.4 \\
\hline Chile (CHL) & 65.4 & 24.1 \\
\hline Colombia (COL) & 46.0 & 9.5 \\
\hline Ecuador (ECU) & 75.7 & 23.2 \\
\hline Mexico (MEX) & 17.5 & 5.3 \\
\hline Peru (PER) & 53.5 & 11.4 \\
\hline Venezuela (VEN) & 80.9 & 25.6 \\
\hline \multicolumn{3}{|c|}{ High Income Commodity Exporting Countries } \\
\hline Australia (AUT) & 49.6 & 9.8 \\
\hline Canada (CAN) & 30.0 & 12.3 \\
\hline New Zealand (NZL) & 48.6 & 15.2 \\
\hline Norway (NOR) & 56.3 & 24.4 \\
\hline
\end{tabular}

1/ Average 1999-2006 
Table 2. Country Specific Commodity Price Indices Composition 1/

(2005, in percentage)

\begin{tabular}{|c|c|c|c|c|c|c|c|c|c|c|c|c|}
\hline & ARG & BRA & $\mathrm{CHL}$ & $\mathrm{COL}$ & ECU & MEX & PER & VEN & AUS & CAN & NZL & NOR \\
\hline Aluminum & 1.9 & 4.9 & 0.1 & 0.6 & 0.3 & 0.3 & 0.0 & 2.1 & 5.6 & 6.1 & 5.4 & 5.0 \\
\hline Banana & 3.0 & 1.6 & 6.0 & 5.2 & 14.1 & 3.7 & 1.6 & 0.0 & 0.7 & 0.1 & 6.4 & 0.0 \\
\hline Barley & 0.2 & 0.0 & 0.0 & 0.0 & 0.0 & 0.0 & 0.0 & 0.0 & 0.9 & 0.3 & 0.0 & 0.0 \\
\hline Beef & 6.9 & 10.6 & 1.6 & 2.0 & 0.0 & 2.2 & 0.0 & 0.0 & 9.3 & 4.0 & 27.8 & 0.0 \\
\hline Butter & 0.1 & 0.0 & 0.0 & 0.0 & 0.0 & 0.0 & 0.0 & 0.0 & 0.3 & 0.0 & 5.3 & 0.0 \\
\hline Cheese & 0.6 & 0.1 & 0.2 & 0.1 & 0.0 & 0.0 & 0.0 & 0.0 & 1.0 & 0.1 & 6.0 & 0.1 \\
\hline Chicken & 0.0 & 0.0 & 0.0 & 0.0 & 0.0 & 0.0 & 0.0 & 0.0 & 0.0 & 0.0 & 0.0 & 0.0 \\
\hline Coal & 0.0 & 0.0 & 0.0 & 25.0 & 0.0 & 0.0 & 0.0 & 0.7 & 26.9 & 2.8 & 0.0 & 0.0 \\
\hline Cocoa & 0.4 & 0.9 & 0.1 & 0.5 & 2.1 & 0.3 & 0.4 & 0.0 & 0.2 & 0.7 & 0.6 & 0.0 \\
\hline Coconut oil & 0.0 & 0.0 & 0.0 & 0.0 & 0.0 & 0.0 & 0.0 & 0.0 & 0.0 & 0.0 & 0.0 & 0.0 \\
\hline Coffee & 0.0 & 6.9 & 0.0 & 15.7 & 1.1 & 0.8 & 3.2 & 0.0 & 0.1 & 0.2 & 0.0 & 0.0 \\
\hline Copper & 3.4 & 1.7 & 64.4 & 0.3 & 0.0 & 2.5 & 37.1 & 0.0 & 5.3 & 2.8 & 0.2 & 0.3 \\
\hline Cotton & 0.2 & 1.3 & 0.0 & 0.2 & 0.1 & 1.0 & 0.5 & 0.0 & 1.3 & 0.2 & 0.0 & 0.0 \\
\hline Cotton seed oil & 0.0 & 0.1 & 0.0 & 0.0 & 0.0 & 0.0 & 0.0 & 0.0 & 0.0 & 0.0 & 0.0 & 0.0 \\
\hline Crude oil & 11.6 & 9.9 & 0.0 & 38.8 & 66.8 & 74.7 & 2.0 & 96.7 & 7.8 & 23.3 & 2.2 & 61.5 \\
\hline Eggs & 0.0 & 0.1 & 0.0 & 0.0 & 0.0 & 0.0 & 0.1 & 0.0 & 0.0 & 0.0 & 0.0 & 0.0 \\
\hline Fish & 3.5 & 1.0 & 9.1 & 1.7 & 12.1 & 1.6 & 3.4 & 0.1 & 1.5 & 3.3 & 6.9 & 6.3 \\
\hline Groundnut oil & 0.3 & 0.0 & 0.0 & 0.0 & 0.0 & 0.0 & 0.0 & 0.0 & 0.0 & 0.0 & 0.0 & 0.0 \\
\hline Groundnuts & 0.2 & 0.1 & 0.0 & 0.0 & 0.0 & 0.0 & 0.0 & 0.0 & 0.0 & 0.0 & 0.0 & 0.0 \\
\hline Hides & 0.0 & 0.0 & 0.0 & 0.1 & 0.0 & 0.4 & 0.0 & 0.0 & 0.8 & 0.5 & 1.2 & 0.1 \\
\hline Iron & 0.0 & 0.0 & 0.0 & 0.0 & 0.0 & 0.0 & 0.0 & 0.0 & 0.4 & 0.8 & 0.5 & 0.1 \\
\hline Iron ore & 0.1 & 17.1 & 1.1 & 0.1 & 0.0 & 0.3 & 2.3 & 0.0 & 13.5 & 1.3 & 0.1 & 0.1 \\
\hline Jute & 0.0 & 0.0 & 0.0 & 0.0 & 0.0 & 0.0 & 0.0 & 0.0 & 0.0 & 0.0 & 0.0 & 0.0 \\
\hline Lead & 0.1 & 0.0 & 0.0 & 0.0 & 0.0 & 0.1 & 4.6 & 0.0 & 1.4 & 0.2 & 0.1 & 0.0 \\
\hline Linseed oil & 0.0 & 0.0 & 0.0 & 0.0 & 0.0 & 0.0 & 0.0 & 0.0 & 0.0 & 0.0 & 0.0 & 0.0 \\
\hline Maize & 6.2 & 0.3 & 0.3 & 0.0 & 0.1 & 0.0 & 0.1 & 0.0 & 0.1 & 0.3 & 0.0 & 0.0 \\
\hline Manganese ores & 0.0 & 0.3 & 0.0 & 0.0 & 0.0 & 0.0 & 0.0 & 0.0 & 0.6 & 0.0 & 0.0 & 0.0 \\
\hline Milk & 1.9 & 0.2 & 0.2 & 0.4 & 0.0 & 0.2 & 0.4 & 0.0 & 1.6 & 0.1 & 17.7 & 0.0 \\
\hline Nat gas & 5.6 & 0.1 & 0.2 & 0.2 & 0.0 & 0.2 & 0.9 & 0.0 & 5.6 & 29.6 & 0.0 & 23.7 \\
\hline Nickel & 0.0 & 0.6 & 0.0 & 0.0 & 0.0 & 0.0 & 0.0 & 0.0 & 1.6 & 3.2 & 0.0 & 1.6 \\
\hline Olive oil & 0.2 & 0.0 & 0.0 & 0.0 & 0.0 & 0.0 & 0.0 & 0.0 & 0.0 & 0.0 & 0.0 & 0.0 \\
\hline Palm oil & 0.0 & 0.0 & 0.0 & 0.9 & 0.6 & 0.0 & 0.0 & 0.0 & 0.0 & 0.0 & 0.0 & 0.0 \\
\hline Pepper & 0.0 & 0.2 & 0.1 & 0.1 & 0.0 & 0.1 & 1.0 & 0.0 & 0.0 & 0.0 & 0.0 & 0.0 \\
\hline Platinum & 0.0 & 0.0 & 0.0 & 0.1 & 0.0 & 0.0 & 0.0 & 0.0 & 0.0 & 0.0 & 0.0 & 0.2 \\
\hline Poultry & 0.0 & 0.0 & 0.0 & 0.0 & 0.0 & 0.0 & 0.0 & 0.0 & 0.0 & 0.1 & 0.1 & 0.0 \\
\hline Rice & 0.4 & 0.1 & 0.0 & 0.0 & 0.2 & 0.0 & 0.0 & 0.0 & 0.1 & 0.0 & 0.0 & 0.0 \\
\hline Rubber & 0.2 & 0.7 & 0.0 & 0.0 & 0.0 & 0.6 & 0.0 & 0.0 & 0.0 & 0.3 & 0.0 & 0.0 \\
\hline Silver & 0.1 & 0.2 & 0.7 & 0.4 & 0.0 & 1.9 & 3.6 & 0.0 & 0.2 & 0.5 & 0.0 & 0.0 \\
\hline Soft Log & 0.6 & 3.1 & 3.7 & 0.1 & 0.5 & 0.3 & 1.3 & 0.0 & 0.2 & 9.0 & 7.2 & 0.2 \\
\hline Soy oil & 13.4 & 3.0 & 0.0 & 0.1 & 0.0 & 0.2 & 0.0 & 0.0 & 0.1 & 0.5 & 0.0 & 0.0 \\
\hline Soybean meal & 17.7 & 7.0 & 0.0 & 0.1 & 0.3 & 0.2 & 12.4 & 0.0 & 0.9 & 0.6 & 1.0 & 0.2 \\
\hline Soybeans & 10.2 & 12.5 & 0.0 & 0.0 & 0.0 & 0.0 & 0.0 & 0.0 & 0.0 & 0.3 & 0.0 & 0.0 \\
\hline Sugar & 1.9 & 10.2 & 0.6 & 5.3 & 1.2 & 2.9 & 0.4 & 0.0 & 0.7 & 1.8 & 4.6 & 0.1 \\
\hline Swine & 0.0 & 0.2 & 0.0 & 0.0 & 0.0 & 0.1 & 0.0 & 0.0 & 0.0 & 0.7 & 0.0 & 0.0 \\
\hline Tea & 0.3 & 0.1 & 0.0 & 0.0 & 0.0 & 0.0 & 0.0 & 0.0 & 0.0 & 0.0 & 0.0 & 0.0 \\
\hline Tin & 0.0 & 0.2 & 11.1 & 1.0 & 0.1 & 2.9 & 14.3 & 0.1 & 0.9 & 1.3 & 0.5 & 0.1 \\
\hline Tobbaco & 0.9 & 3.9 & 0.0 & 0.1 & 0.3 & 0.1 & 0.1 & 0.0 & 0.0 & 0.1 & 0.0 & 0.0 \\
\hline Uranium & 0.0 & 0.0 & 0.0 & 0.0 & 0.0 & 0.0 & 0.0 & 0.0 & 0.7 & 0.0 & 0.0 & 0.0 \\
\hline Wheat & 7.0 & 0.3 & 0.3 & 0.8 & 0.0 & 1.5 & 0.5 & 0.1 & 4.4 & 3.9 & 2.4 & 0.0 \\
\hline Wool & 0.7 & 0.0 & 0.1 & 0.0 & 0.0 & 0.0 & 0.3 & 0.0 & 2.8 & 0.0 & 3.8 & 0.0 \\
\hline Zinc & 0.1 & 0.2 & 0.1 & 0.0 & 0.0 & 1.1 & 9.3 & 0.0 & 2.2 & 0.8 & 0.0 & 0.3 \\
\hline
\end{tabular}

1/ Highlighted commodities represent more than 50 percent of each index composition. 


\section{Table 3. Commodity Price Shocks as a Source of Primary Expenditure Fluctuations}

(Contribution of commodity price shocks to the variance of primary expenditure growth)

\begin{tabular}{ccccccccc}
\hline $\begin{array}{c}\text { Quarters } \\
\text { after the } \\
\text { shock }\end{array}$ & VEN & COL & ARG & ECU & MEX & BRA & PER & CHL \\
\hline 1 & 5.73 & 6.84 & 0.02 & 4.19 & 10.57 & 2.61 & 1.56 & 0.60 \\
2 & 14.52 & 11.13 & 0.60 & 9.69 & 6.74 & 7.38 & 1.49 & 1.96 \\
4 & 16.83 & 15.57 & 12.97 & 9.47 & 8.22 & 7.42 & 3.40 & 3.64 \\
8 & 16.61 & 14.32 & 12.47 & 9.69 & 8.23 & 7.84 & 4.12 & 3.92 \\
10 & 16.59 & 14.26 & 12.90 & 9.72 & 8.23 & 7.85 & 4.12 & 3.92 \\
\hline
\end{tabular}

\begin{tabular}{ccccc}
\hline $\begin{array}{c}\text { Quarters } \\
\text { after the } \\
\text { shock }\end{array}$ & CAN & NZL & NOR & AUT \\
\hline 1 & 0.38 & 0.00 & 0.86 & 0.60 \\
2 & 1.79 & 3.26 & 2.72 & 0.54 \\
4 & 5.54 & 5.26 & 3.47 & 1.49 \\
8 & 5.70 & 5.39 & 2.92 & 1.50 \\
10 & 5.71 & 5.39 & 2.91 & 1.50 \\
\hline
\end{tabular}


Table 4. Sample Period by Country

(For Real GDP, Primary Expenditures and Revenues)

\begin{tabular}{|c|c|c|}
\hline Country & Beginning Date & End Date \\
\hline ARG & 1993Q1 & 2008Q4 \\
\hline BRA & 1993Q1 & $2008 Q 4$ \\
\hline $\mathrm{CHL}$ & 1995Q1 & 2008Q4 \\
\hline $\mathrm{COL}$ & 1995Q1 & $2008 Q 4$ \\
\hline ECU & 1998Q1 & 2008Q4 \\
\hline MEX & 1993Q1 & $2008 Q 4$ \\
\hline PER & 1995Q1 & 2008Q4 \\
\hline VEN & 1998Q1 & $2008 Q 4$ \\
\hline AUT & 1975Q1 & 2008Q4 \\
\hline CAN & 1985Q2 & 2008Q4 \\
\hline NZL1/ & 1988Q1 & 2008Q4 \\
\hline NOR & 1991Q1 & $2008 Q 4$ \\
\hline
\end{tabular}

1/ Primary Expenditure not available at quarterly frequency; therefore I will use Government Consumption Expenditure as a proxy. Revenue series are not available at a quarterly frequency. 


\section{Table 5. Responses to Commodity Price Shocks}

(Response to one standard deviation shock, quarterly percentage change)

\begin{tabular}{|c|c|c|c|c|c|c|c|c|c|}
\hline & \multicolumn{3}{|c|}{ Primary Expenditures } & \multicolumn{3}{|c|}{ Revenues } & \multicolumn{3}{|c|}{ GDP } \\
\hline & Impact Response & $\begin{array}{l}\text { Peak Response } \\
\text { (max deviation) }\end{array}$ & $\begin{array}{l}\text { Quarter of the } \\
\text { Peak Response }\end{array}$ & Impact Response & $\begin{array}{l}\text { Peak Response } \\
\text { (max deviation) }\end{array}$ & $\begin{array}{l}\text { Quarter of the } \\
\text { Peak Response }\end{array}$ & Impact Response & $\begin{array}{l}\text { Peak Response } \\
\text { (max deviation) }\end{array}$ & $\begin{array}{l}\text { Quarter of the } \\
\text { Peak Response }\end{array}$ \\
\hline Argentina & 0.0 & 2.0 & 4th & 1.3 & 2.9 & 2nd & 0.3 & 0.5 & 2nd \\
\hline Brazil & 0.0 & 0.7 & $2 n d$ & 0.8 & 0.3 & $1 \mathrm{st}$ & 0.8 & 0.8 & $1 \mathrm{st}$ \\
\hline Chile & 0.0 & 0.0 & - & 1.3 & 2.1 & 2nd & 0.5 & 0.5 & $1 \mathrm{st}$ \\
\hline Colombia & 2.0 & 3.0 & $2 n d$ & 0.0 & 1.7 & 4th & 0.4 & 0.5 & $2 n d$ \\
\hline Ecuador & 3.0 & 4.8 & $2 n d$ & 6.4 & 7.1 & 2nd & 0.5 & 0.5 & $1 s t$ \\
\hline Mexico & 2.1 & 2.1 & $1 \mathrm{st}$ & 0.8 & 2.0 & $2 n d$ & 0.3 & 0.3 & $1 \mathrm{st}$ \\
\hline Peru & 0.7 & 1.0 & $3 r d$ & 2.0 & 2.0 & $1 \mathrm{st}$ & 0.1 & 0.7 & 2 nd \\
\hline Venezuela & 3.0 & 5.3 & $2 n d$ & 2.6 & 6.5 & $2 n d$ & 0.0 & 1.2 & $2 n d$ \\
\hline Australia & 0.0 & -0.6 & $3 r d$ & 1.0 & 1.0 & $1 \mathrm{st}$ & 0.2 & 0.2 & $1 \mathrm{st}$ \\
\hline Canada & 0.0 & 0.6 & $3 r d$ & 0.0 & 0.5 & $3 r d$ & 0.6 & 0.6 & $1 \mathrm{st}$ \\
\hline New Zealand & 0.0 & 0.1 & $2 n d$ & - & - & - & 0.0 & 0.1 & $2 n d$ \\
\hline Norway & -0.4 & -0.9 & 2nd & 1.8 & 1.8 & $1 \mathrm{st}$ & 1.5 & 1.5 & $1 \mathrm{st}$ \\
\hline
\end{tabular}


Figure 1. Country Specific Commodity Price Indices

(2005=100, in nominal US\$)
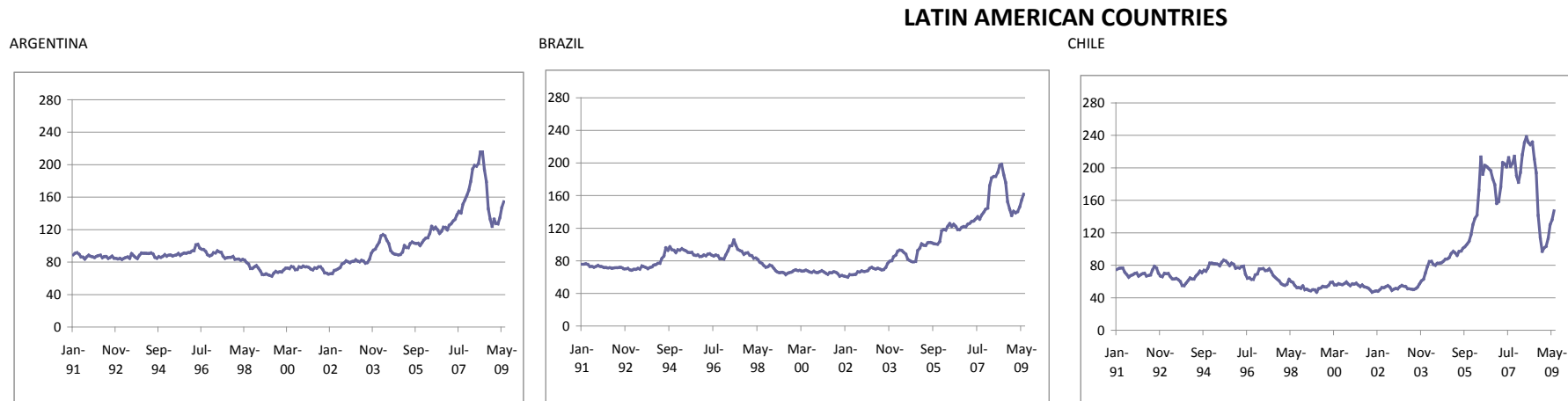

ECUADR

MEXICO

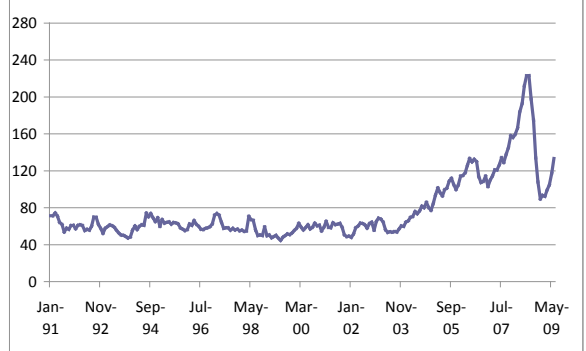

$\begin{array}{cccccccccccc}\text { Jan- } & \text { Nov- Sep- } & \text { Jul- } & \text { May- Mar- } & \text { Jan- } & \text { Nov- } & \text { Sep- } & \text { Jul- } & \text { May- } \\ 91 & 92 & 94 & 96 & 98 & 00 & 02 & 03 & 05 & 07 & 09\end{array}$

AUSTRALIA

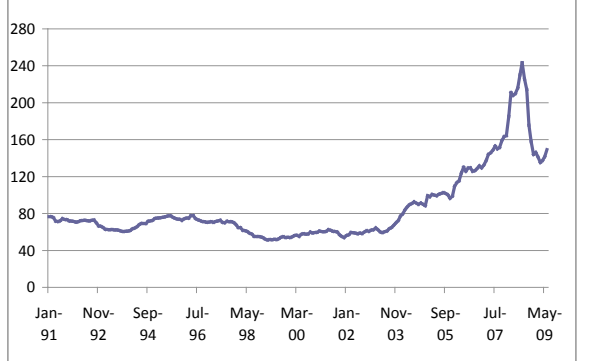

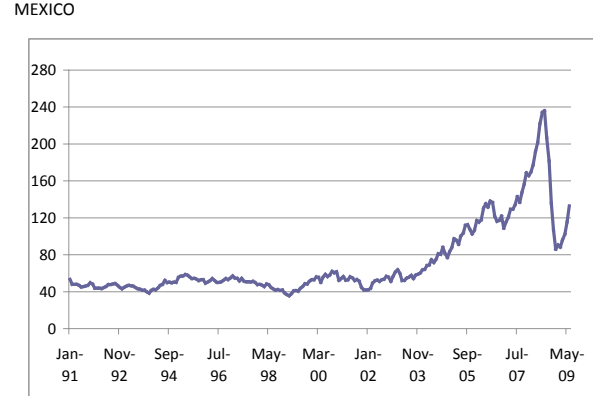
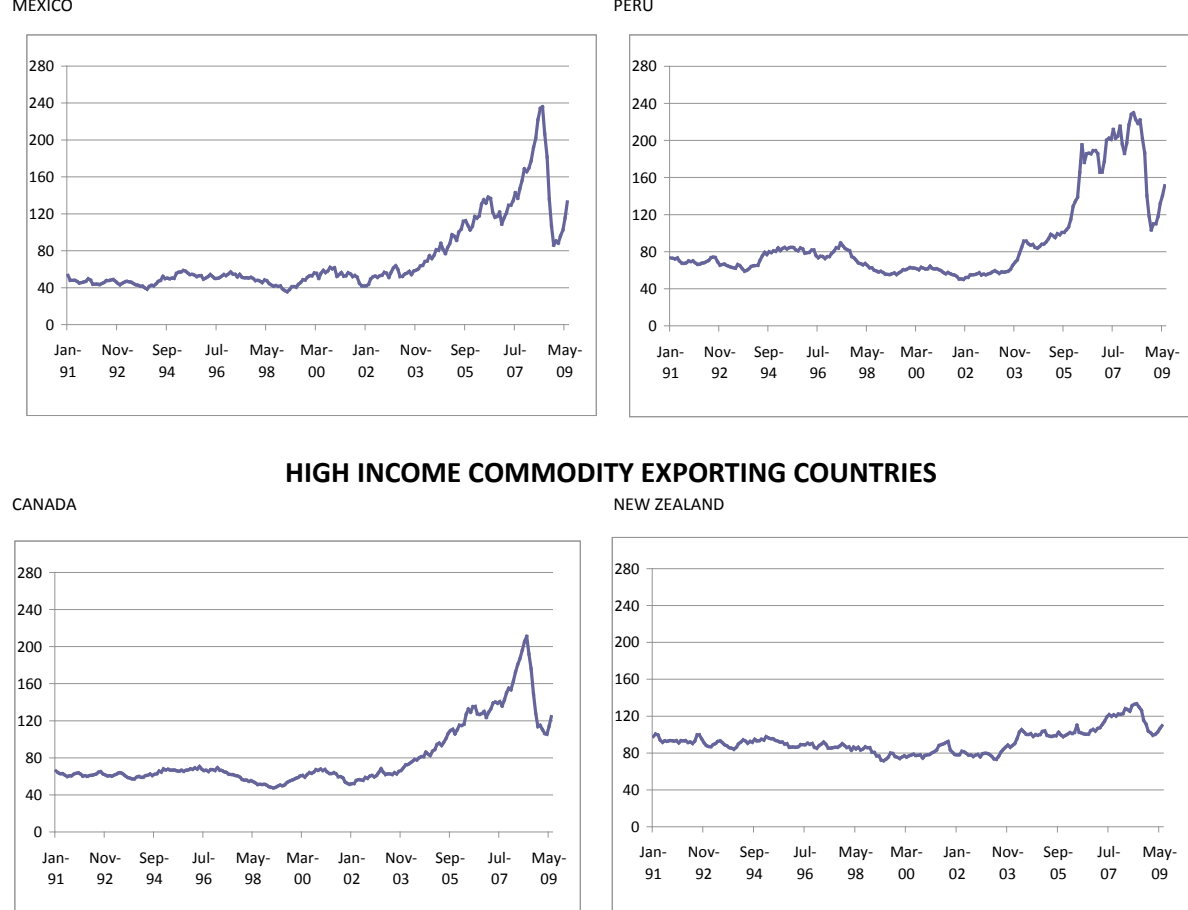

\section{HIGH INCOME COMMODITY EXPORTING COUNTRIES}

PERU

COLOMBIA

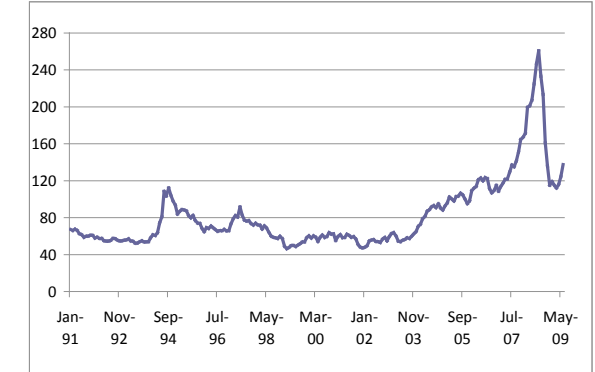

VENEZUELA

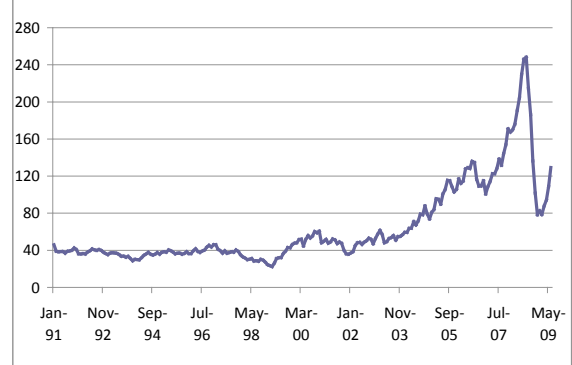

NORWAY

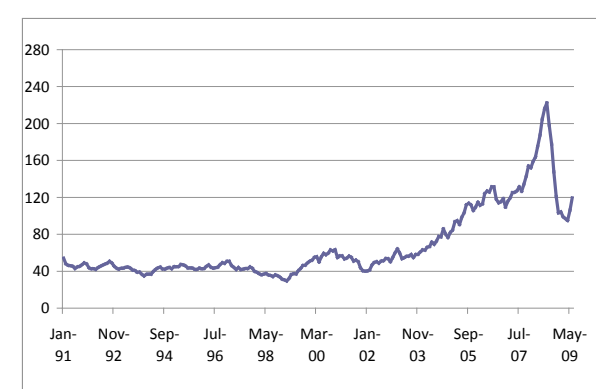


Figure 2. Commodity-Related Fiscal Revenues

(In percentage of GDP)

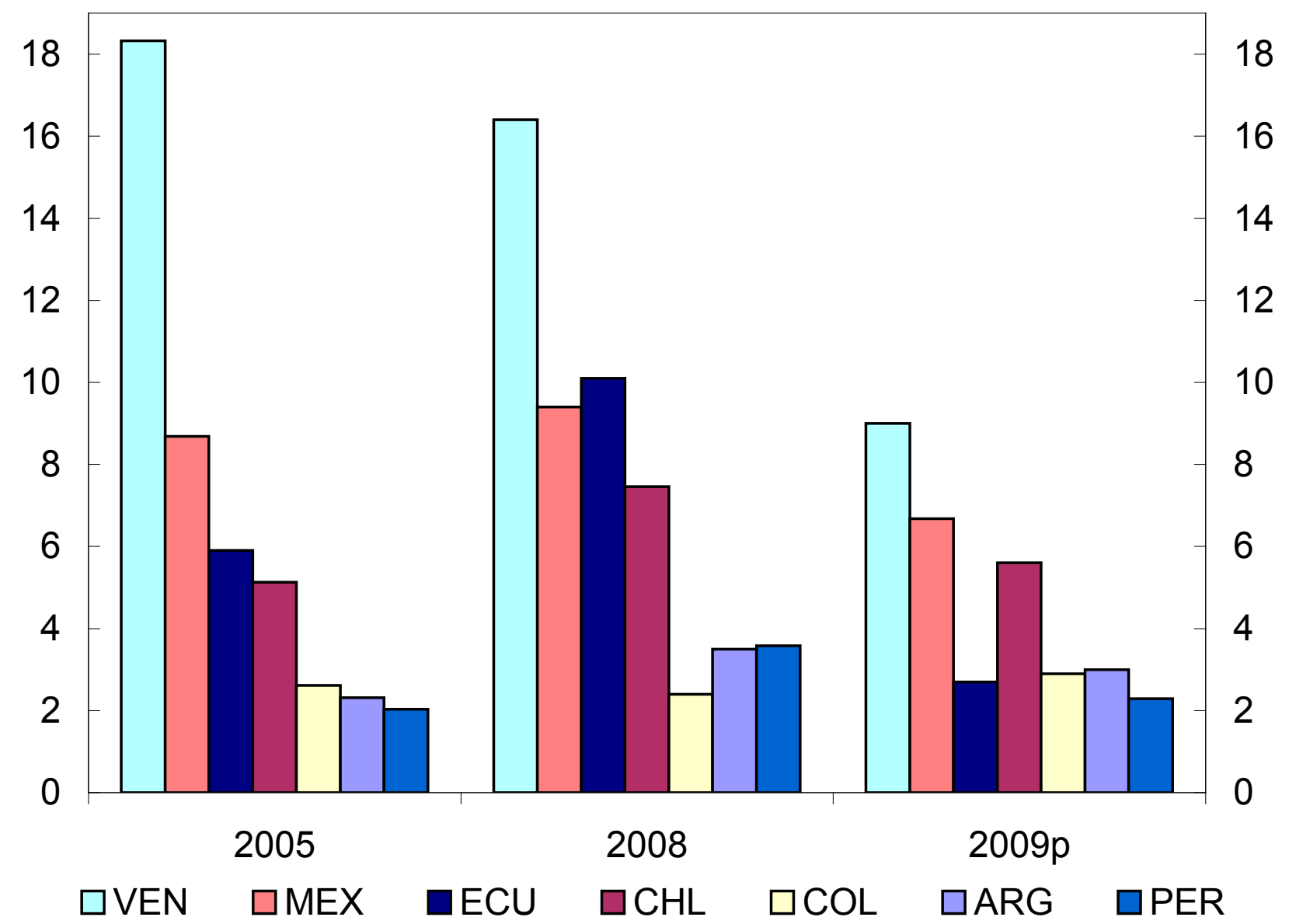


Figure 3. Contribution of Commodity Price Shocks to the Variance of Primary Expenditure Growth (In percentage)

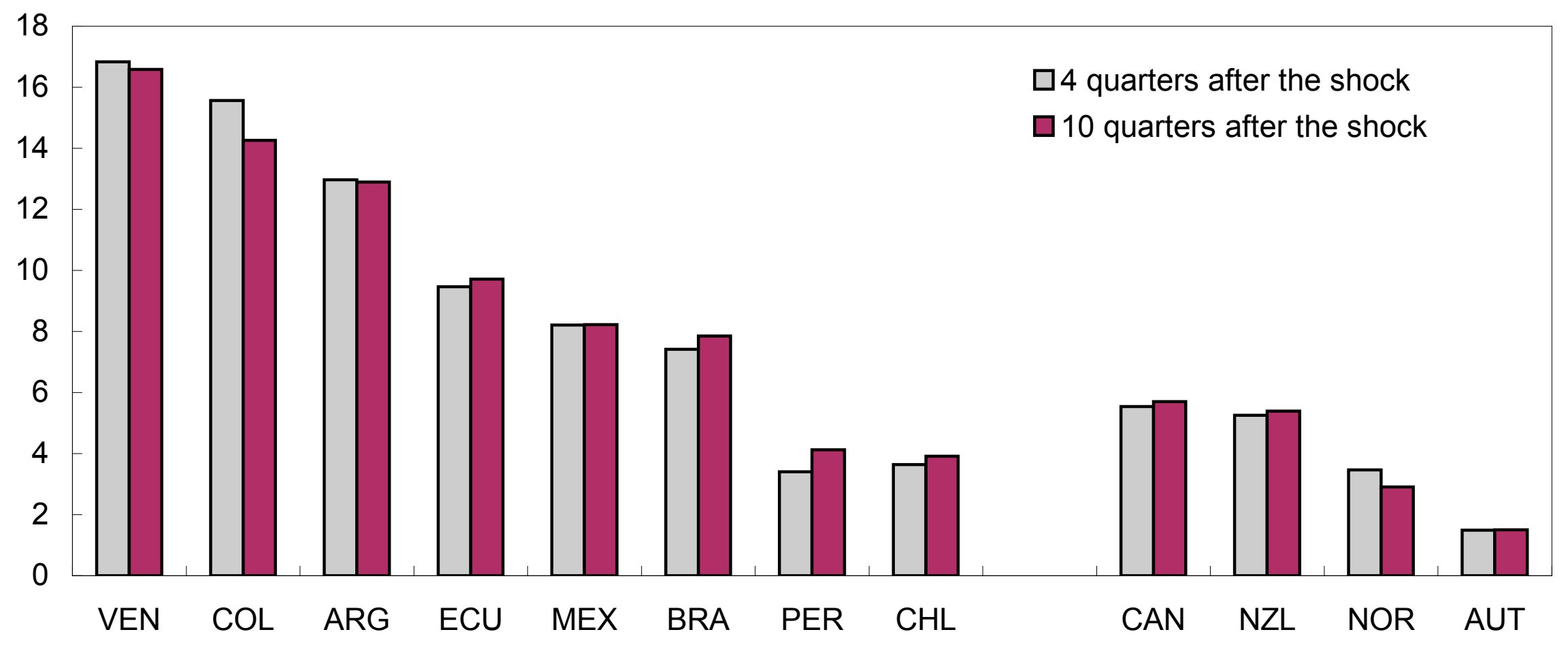


Figure 4. Response of Commodity Prices to Commodity Price One Standard Cholesky Innovation

(In percentage)
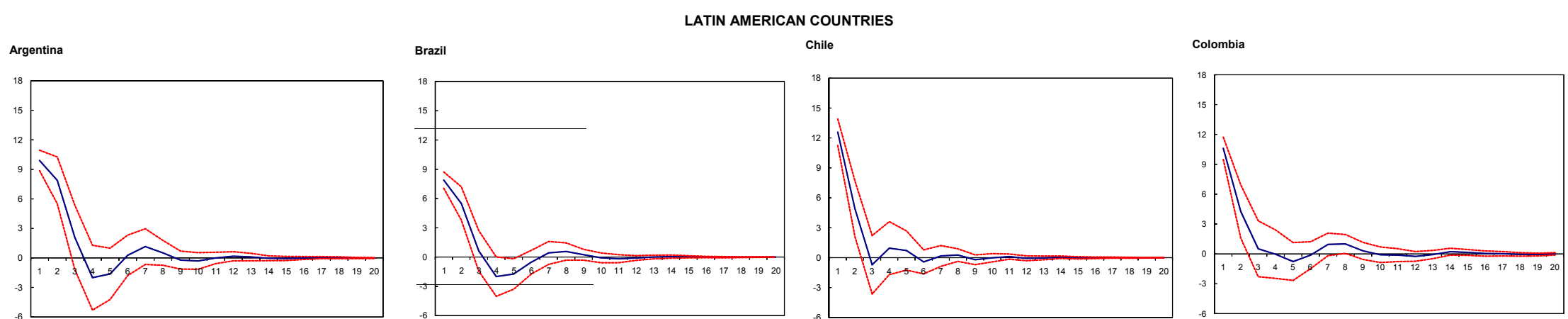

Ecuador

\section{Mexico}

Peru
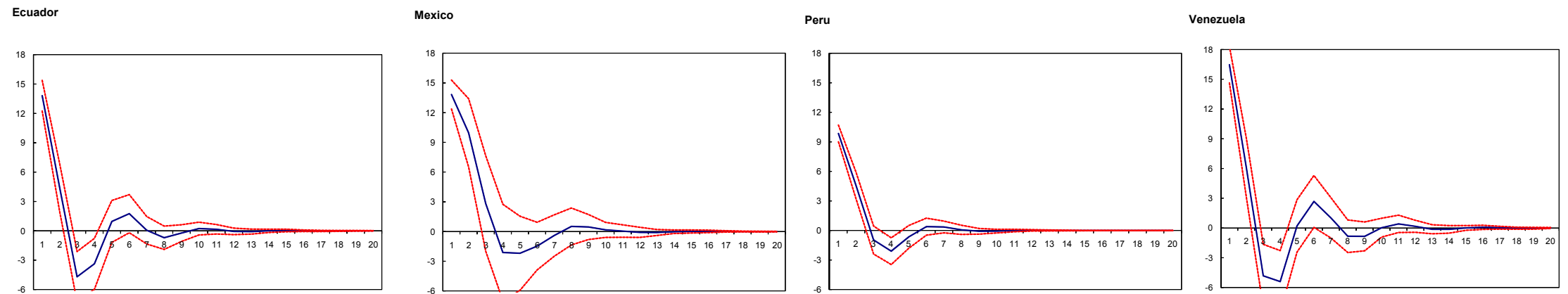

HIGH-INCOME COMMODITY EXPORTING COUNTRIES

Canada

$$
\text { New Zealand }
$$

Norway
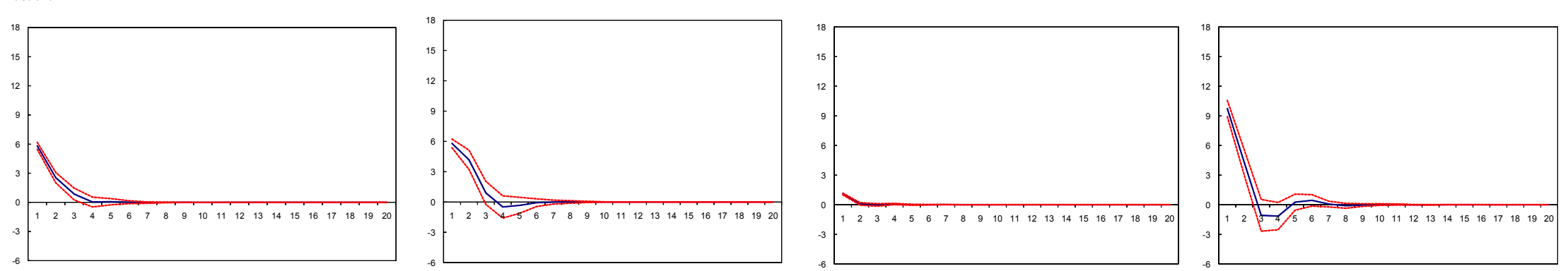
Figure 5. Accumulated Response of Commodity Prices to Commodity Price One Standard Cholesky Innovation (In percentage)
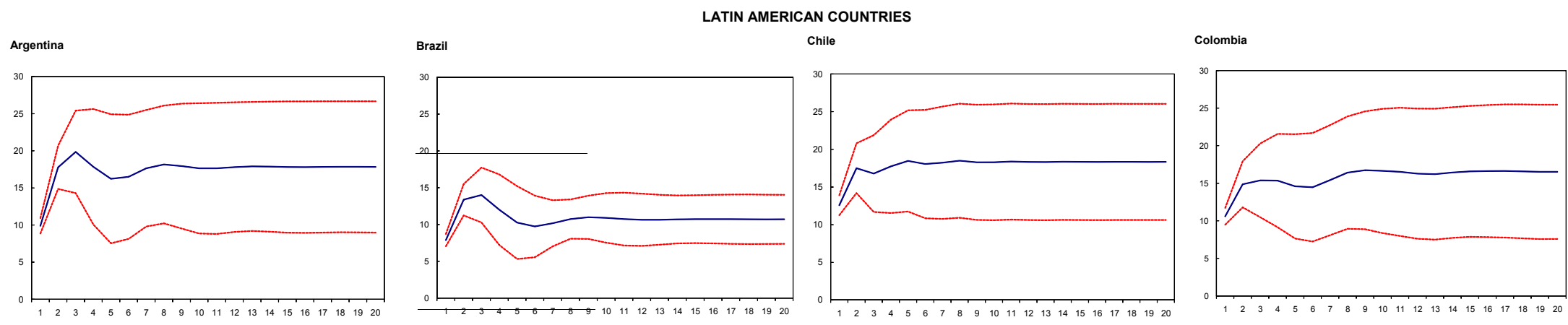

Ecuador

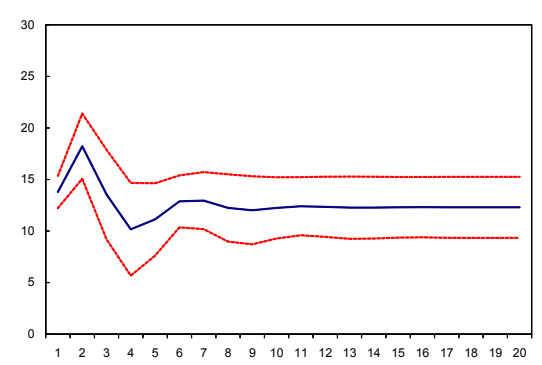

Australia

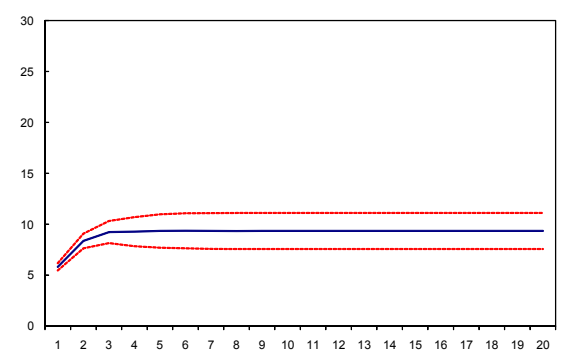

Mexico

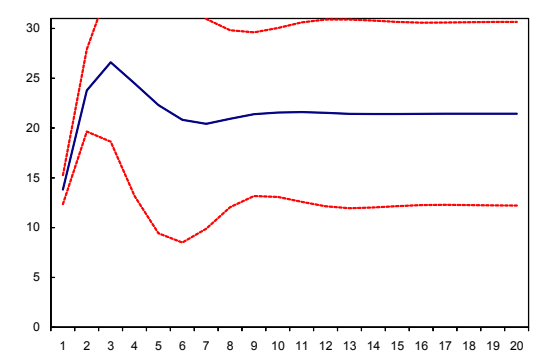

HIGH-INCOME COMM

Peru

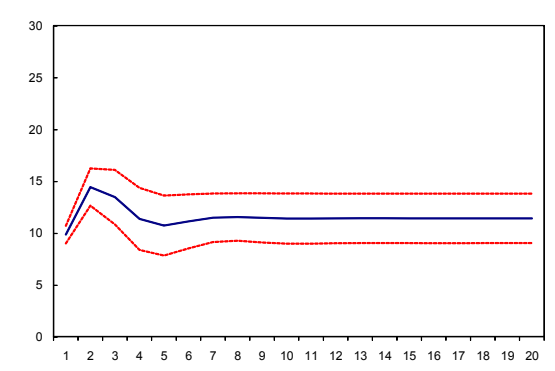

New Zealand

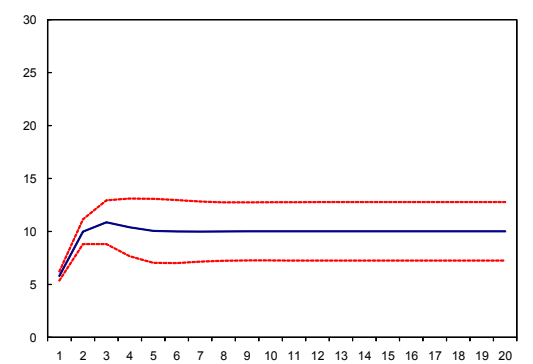

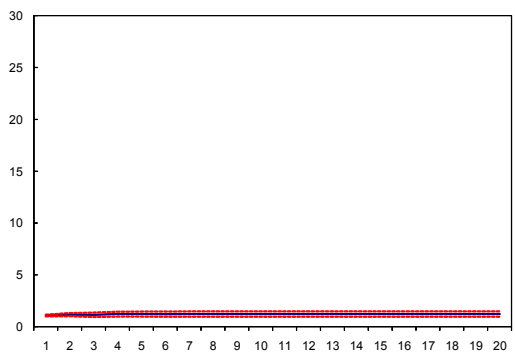

Norway

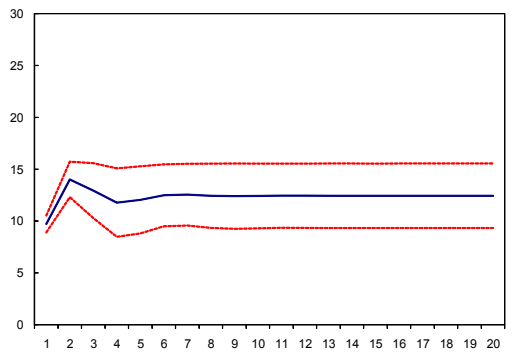




\section{Figure 6. Accumulated Response of Primary Expenditures to Commodity Price One Standard Cholesky Innovation}

(In percentage)
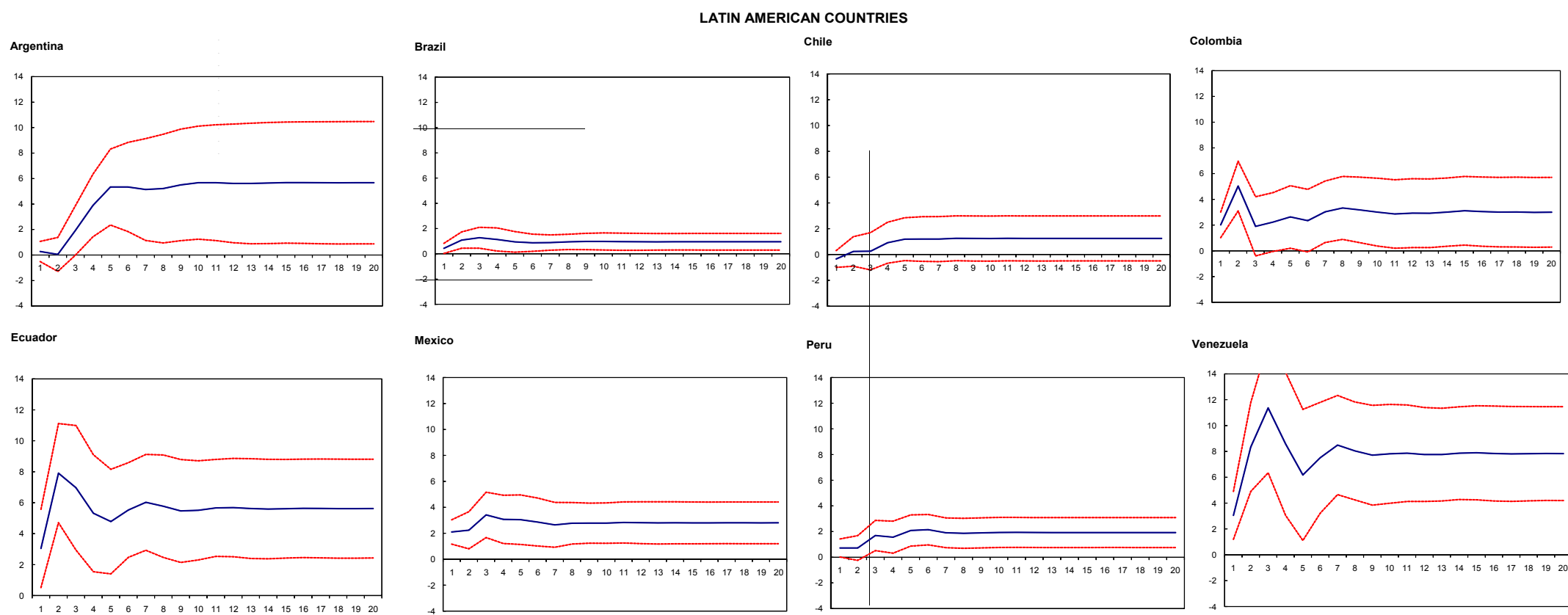

Mexico
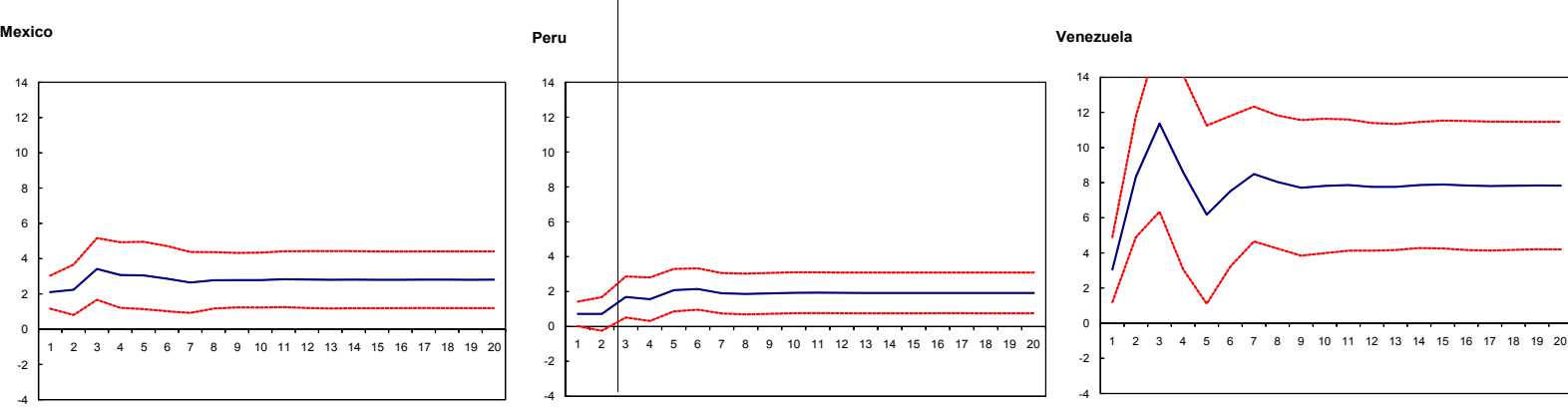

Australia
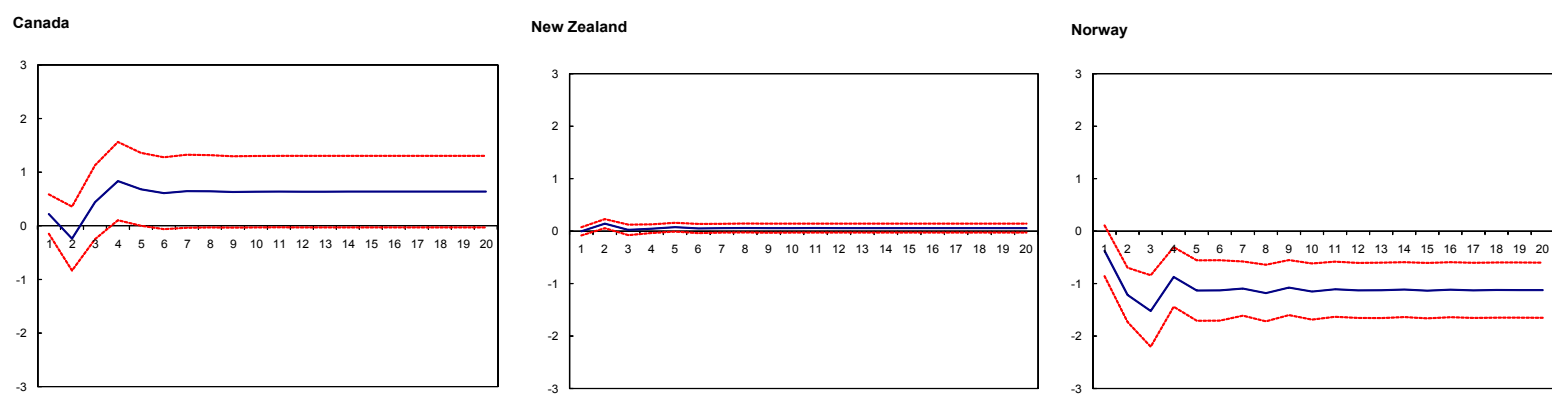
Figure 7. Accumulated Response of Total Revenues to Commodity Price One Standard Cholesky Innovation (In percentage)
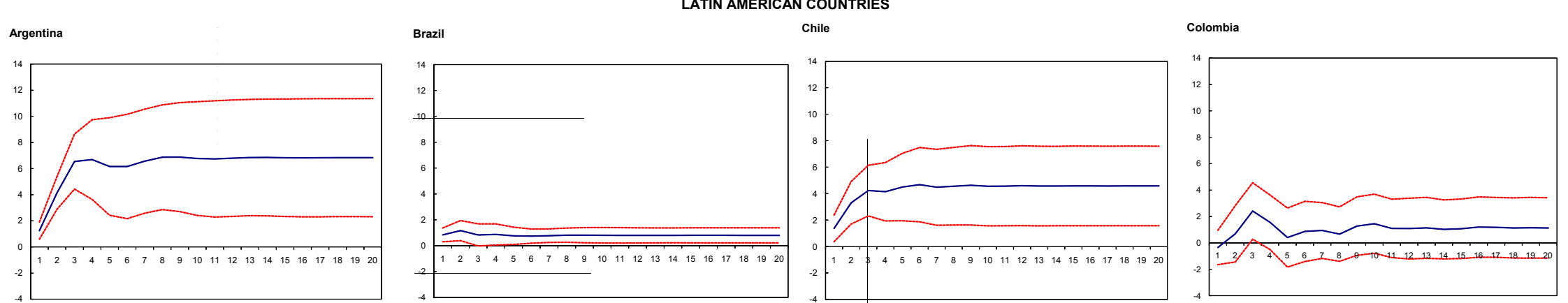

Ecuador

Mexico
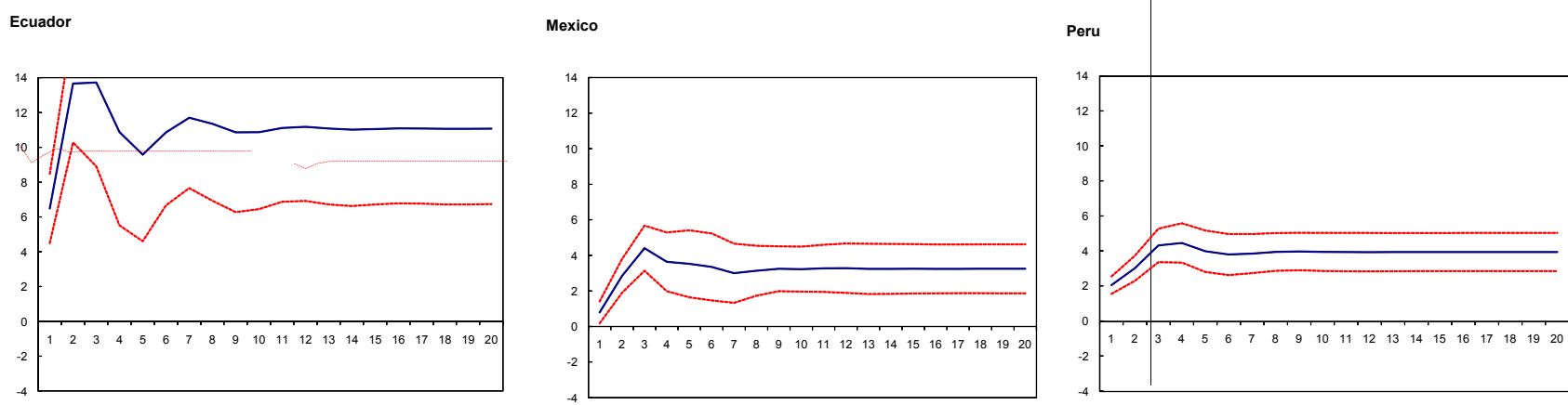

Venezuela

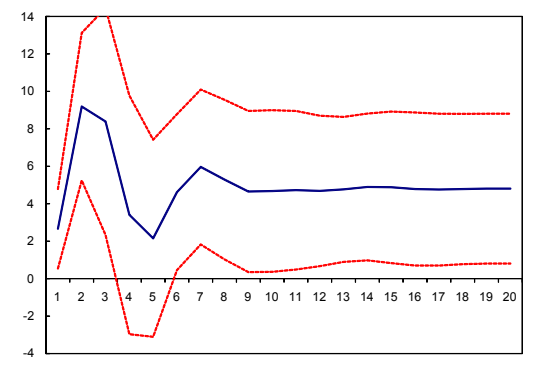

Australia

Canada

HIGH-INCOME COMMODITY EXPORTING COUNTRIES
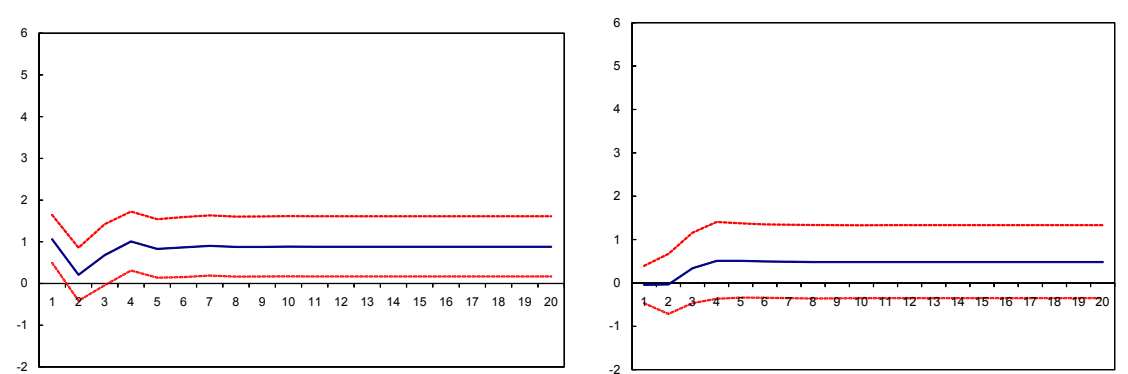
Norway

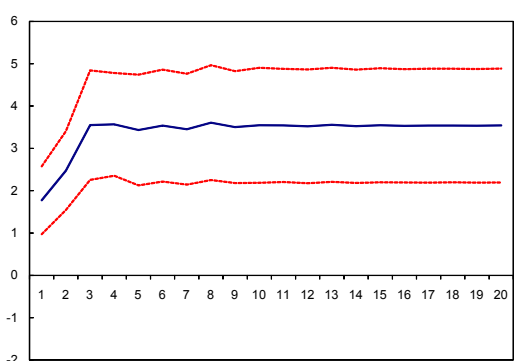


Figure 8. Accumulated Response of GDP to Commodity Price One Standard Cholesky Innovation

(In percentage)
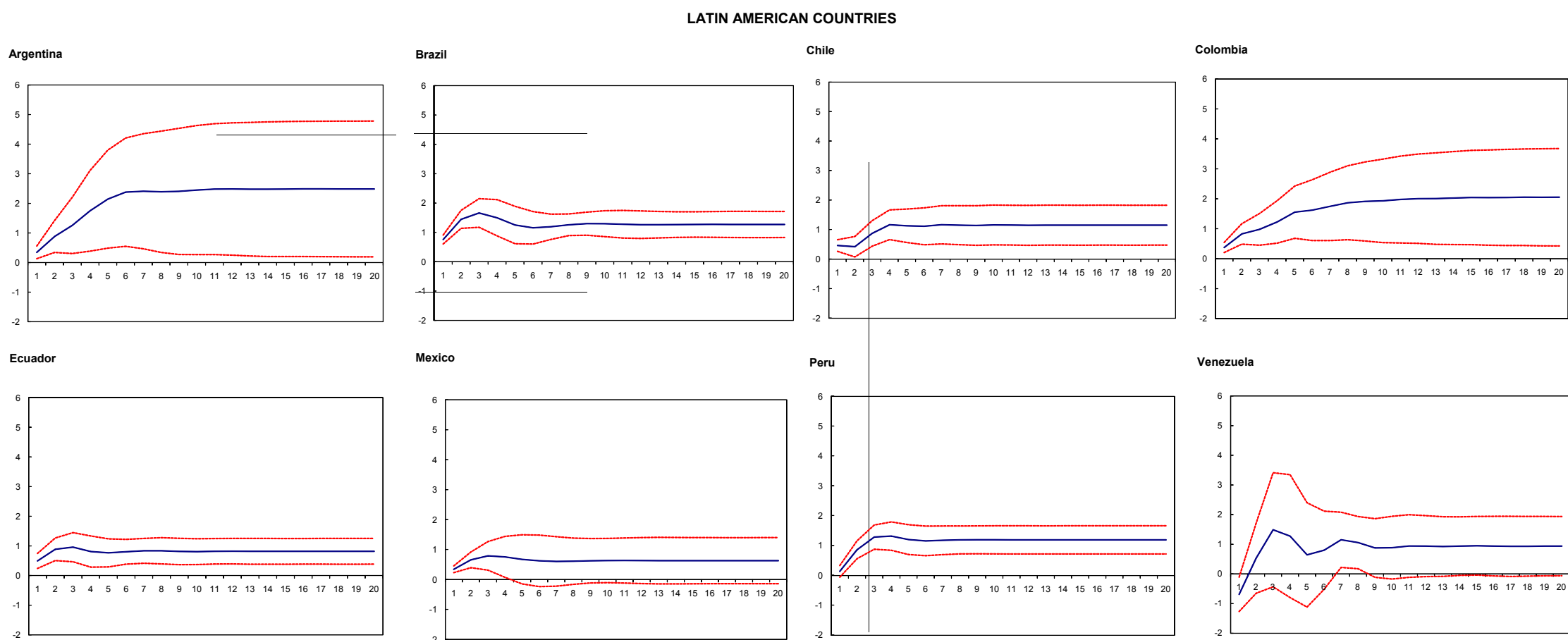

$$
\text { Mexico }
$$
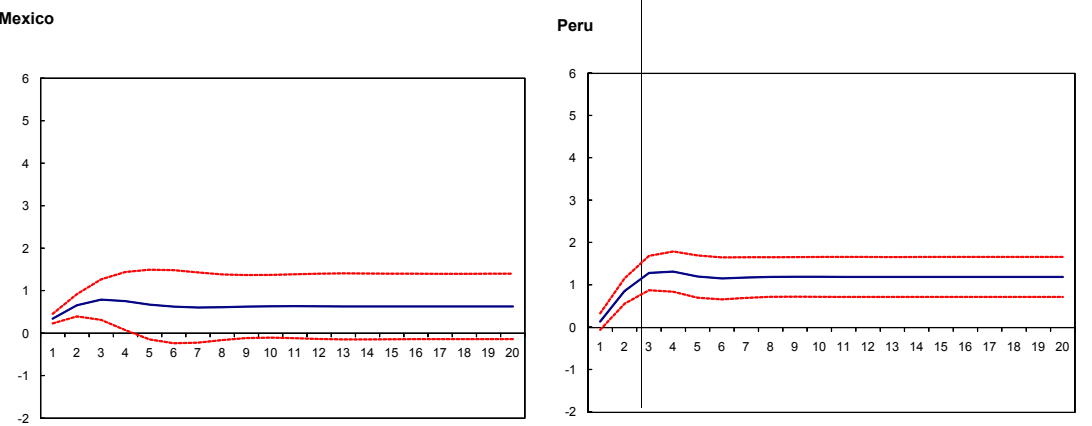

Venezuela

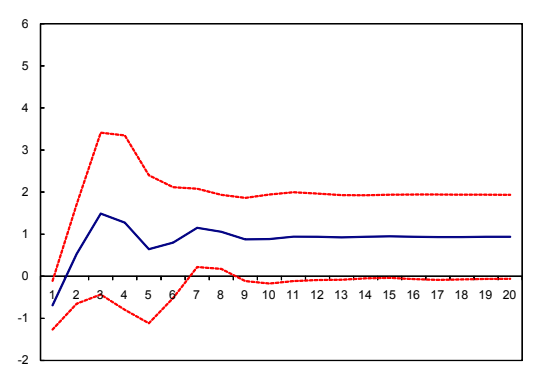

HIGH-INCOME COMMODITY EXPORTING COUNTRIES
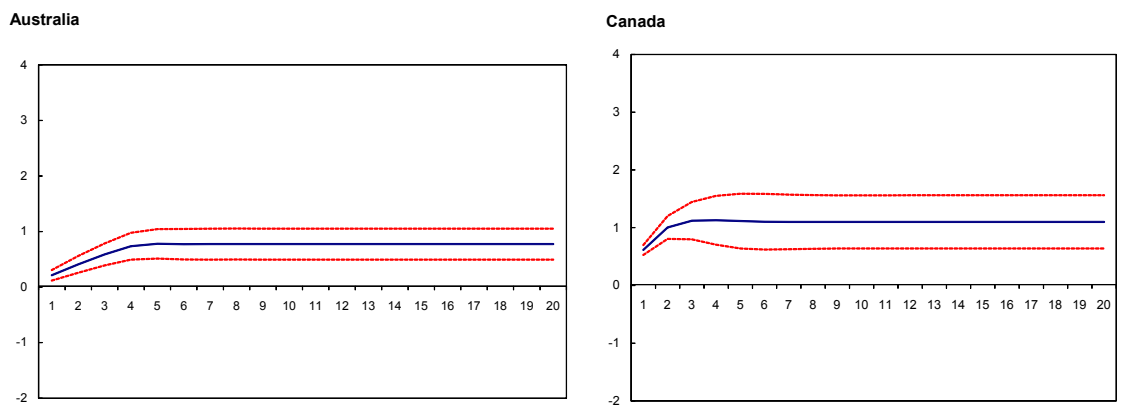

New Zealand

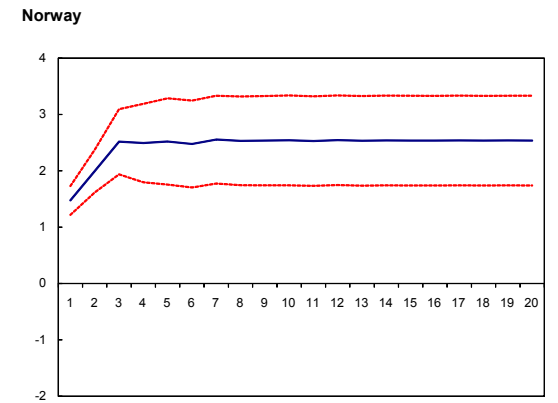

